\title{
FIRST RECORD OF THE LATTICE SOLDIERFISH, MYRIPRISTIS VIOLACEA (ACTINOPTERYGII: HOLOCENTRIFORMES: HOLOCENTRIDAE), FROM REUNION ISLAND (SOUTH-WESTERN INDIAN OCEAN)
}

\author{
Philippe BOURJON ${ }^{*}$ and Ronald FRICKE ${ }^{2}$ \\ ${ }^{1}$ Reunion Island Biodiversity Research Agency, Saint Leu, La Reunion, France \\ ${ }^{2}$ Im Ramstal 76, 97922 Lauda-Königshofen, Germany
}

Bourjon P., Fricke R. 2019. First record of the lattice soldierfish, Myripristis violacea (Actinopterygii: Holocentriformes: Holocentridae), from Reunion Island (south-western Indian Ocean). Acta Ichthyol. Piscat. 49 (4): 415-420.

\begin{abstract}
The lattice soldierfish, Myripristis violacea Bleeker, 1851, is recorded for the first time from Reunion Island. An aggregation of 12 individuals was observed and photographed on 12 January 2019 and later on the L'Hermitage reef, located on the west coast of the island. Examination of high-resolution photographs of the largest of these individuals shows that its external morphological characteristics agree well with those reported in the description of the species provided by the last revision of the genus. Studies on regional connectivity make it likely that the Reunion Island population of M. violacea originates from the northern Seychelles Island or Chagos Archipelago via stepping-stone populations. Our observations extend the known distribution of the species to the southernmost island of the Mascarene Archipelago, and extend its known depth range.
\end{abstract}

Keywords: Myripristis violacea, first record, distribution, Reunion Island, connectivity

\section{INTRODUCTION}

Fishes of the family Holocentridae Bonaparte, 1833 are abundant members of tropical reef assemblages that occur in the Atlantic, Indian and Pacific Oceans (Greenfield 1968). This family includes 90 species distributed in two sub-families: the Holocentrinae Bonaparte, 1833 or squirrelfishes with three genera: Holocentrus Scopoli, 1777; Neoniphon Castelnau, 1875; and Sargocentron Fowler, 1904; covering 44 species, and the Myripristinae Nelson, 1955 or soldierfishes with five genera: Corniger Agassiz in Spix et Agassiz, 1831; Myripristis Cuvier, 1829; Ostichthys Cuvier, 1829; Plectrypops Gill, 1862; and Pristilepis Randall, Shimizu et Yamakawa, 1982 (see Woods and Sonoda 1973, Zehren 1979, Stewart unpublished ${ }^{* *}$ ) covering 46 species (Fricke et al. 2019a). Dornburg et al. (2012) considered the resurrection of a fourth genus in Holocentrinae, Flammeo Jordan et Evermann, 1898, containing the single western Atlantic species Flammeo marianus (Cuvier in Cuvier et Valenciennes, 1829). The most recent checklist of the fish species of Reunion Island included 984 marine and freshwater species belonging to 164 families, with 964 species occurring in marine habitats (Fricke et al. 2009). Among the latter, 26 species of the family Holocentridae were recorded, including five genera:
Neoniphon, Sargocentron, Myripristis, Ostichthys, and Pristilepis. The genus Myripristis contained nine species, Myripristis adusta Bleeker, 1853; Myripristis berndti Jordan et Evermann, 1903; Myripristis botche Cuvier, 1829; Myripristis chryseres Jordan et Evermann, 1903; Myripristis hexagona (Lacepède, 1802); Myripristis kuntee Valenciennes in Cuvier et Valenciennes, 1831; Myripristis murdjan (Forsskål in Niebuhr, 1775); Myripristis seychellensis Cuvier in Cuvier et Valenciennes, 1829; and Myripristis vittata Valenciennes in Cuvier et Valenciennes, 1831. The lattice soldierfish, Myripristis violacea Bleeker, 1851 was not yet recorded from Reunion Island.

Myripristis violacea is a widespread tropical IndoPacific species which can be found west from East Africa, Seychelles, and Madagascar, east to Line, Marquesas and Tuamotu islands, north to the Ryukyu Islands, south to Queensland (Australia) and New Caledonia (Fricke et al. 2019b). This coral-reef dwelling species generally occurs in shallow, protected waters of bays and lagoons, remaining in caves or crevices during the day and foraging at night (Randall and Greenfield 1996). The known depth range of this species is 3-30 m (Allen et al. 2003). Its maximum total length seems to be subject to debate, it may be $35 \mathrm{~cm}$ according to Kuiter and Tonozuka (2001), although Kuiter (1992) gives an estimated total length of

\footnotetext{
" Correspondence: Philippe Bourjon, Agence de Recherche pour la Biodiversité de La Réunion (ARBRE) 18, rue des Seychelles, 97436 Saint Leu, La Réunion, France, phone: 00262 325560, e-mail: (PB) seizhavel@wanadoo.fr, (RF) ronfricke@web.de.

"* Stewart J.D. 1984. Taxonomy, paleoecology, and stratigraphy of the halecostome-inoceramid associations of the North American upper Cretaceous. PhD Dissertation, University of Kansas, Lawrence KS, USA.
} 
$25 \mathrm{~cm}$ for the same species. More reliable, however, seem maximum total lengths of $20 \mathrm{~cm}$ according to Allen et al. (2003) and Lieske and Myers (1994), $22 \mathrm{~cm}$ according to Allen and Erdmann (2012), or $23 \mathrm{~cm}$ according to Randall (1984). To our knowledge, the diet of $M$. violacea has not yet been studied, but Hobson (1972) states that Myripristis amaena (Castelnau, 1873) (as. Myripristis argyromus), M. kuntee (as Myripristis multiradiatus), and M. berndti are known to have nocturnal plankton-feeding habits. Dee and Parrish (1994) showed that the diet of M. amaena was largely dominated by crustacean small juvenile stages or larvae (mainly crabs and shrimps), and considered that their findings provided reasonable approximation for less extensively studied Myripristis species.

\section{MATERIALS AND METHODS}

Observations were carried out by skin diving on the fringing reef of L'Hermitage (also called Saint Gilles-La Saline Reef), located on the Reunion Island west coast. Reunion Island $\left(21^{\circ} 07^{\prime} \mathrm{S}, 055^{\circ} 32^{\prime} \mathrm{E}\right)$ is part of the Mascarene Archipelago (south-western Indian Ocean). It is located about $680 \mathrm{~km}$ east of Madagascar, and $170 \mathrm{~km}$ west-southwest of Mauritius. L'Hermitage reef is less than $8 \mathrm{~km}$ long. Its maximum width is about $500 \mathrm{~m}$, and the mean depth is $1.2 \mathrm{~m}$. This reef is located within the perimeter of the marine protected area "Réserve Naturelle Marine de La Réunion" (RNMR). Our study site is situated in the southern part of the reef $\left(21^{\circ} 5^{\prime} 56.14^{\prime \prime} \mathrm{S}, 055^{\circ} 14^{\prime} 22.91^{\prime \prime} \mathrm{E}\right)$ in a protective zone at level 2A (enhanced protection zone), which is why we did not collect any specimens. Observations were made both day and night.

Twelve individuals of Myripristis violacea were observed on 12 January 2019 about $30 \mathrm{~m}$ from the shore at a depth of $1.2 \mathrm{~m}$. These individuals were aggregated in interconnected caves in an $8 \mathrm{~m}$ long cluster of degraded colonies of the scleractinian coral Acropora muricata. Only those that were visible and relatively stationary were counted by two observers advancing rapidly towards each other from each end of the cluster, which suggests that the number of individuals participating in this aggregation was likely larger. The observed individuals were grouped together with numerous individuals of M. murdjan. We selected the largest individual of Myripristis violacea as a specimen for the description below. It often stood motionless in the entrance of a cave, presenting its profile to the observer (Fig. 1). The total length of this fish was estimated by measuring the width of the cave entrance. Photographs were taken using a Canon Power Shot G10 camera and a Canon EOS 7D body fitted with a Canon 60 mm ESF macro lens.

High-resolution profile photographs taken during daytime were used to estimate total length (TL), standard length (SL), head length (HL), body depth (BD), orbit diameter (OD), snout length and fin-ray counts (dorsal, anal, and pectoral fins). Table 1 compares

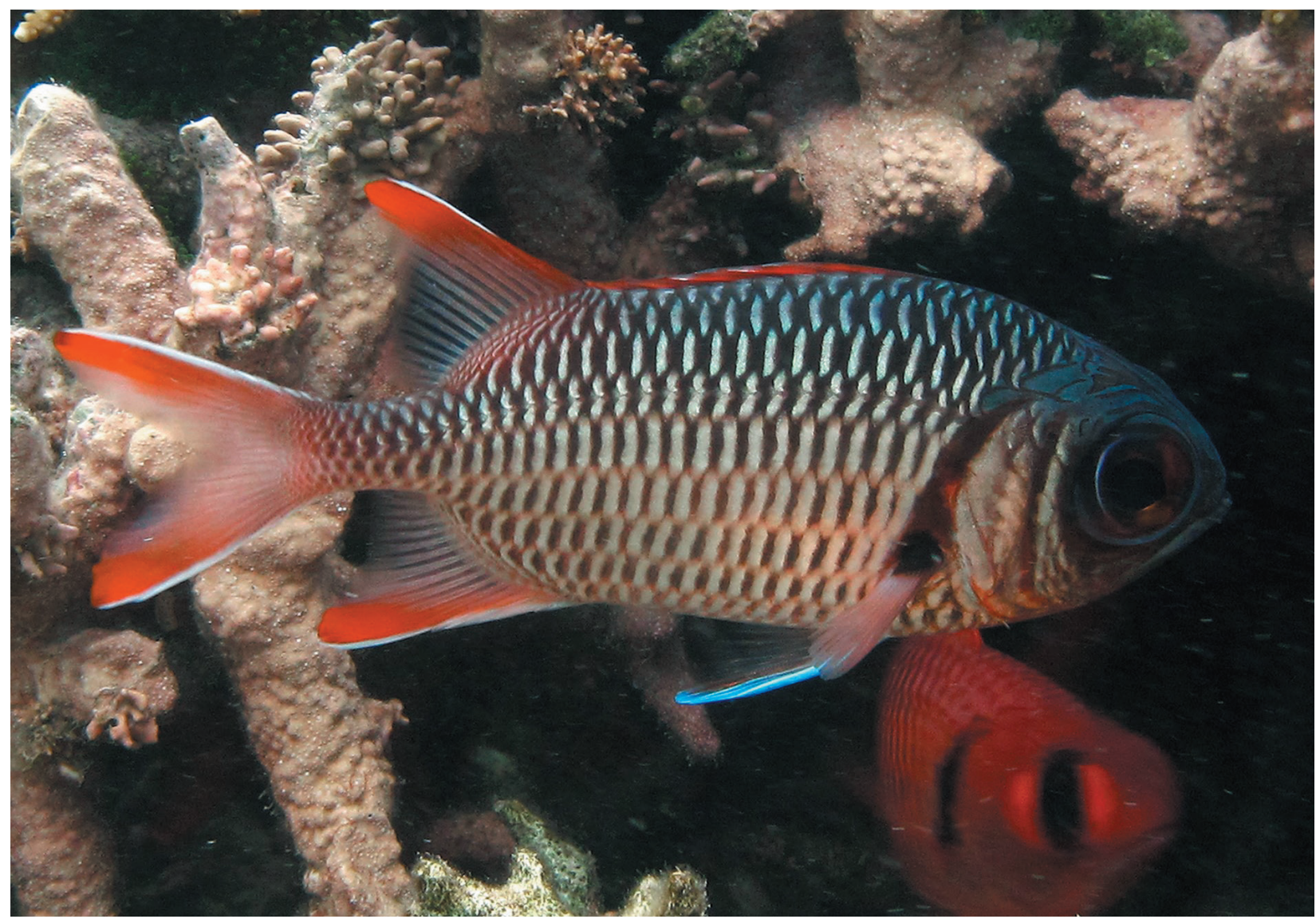

Fig. 1. Myripristis violacea from Reunion Island (with M. murdjan in the background below), 12 January 2019, ca. 10 cm SL (photograph: P. Bourjon) 
these morphometric and meristic characters of the fish specimen with data from Randall and Greenfield's (1996) revisionary description of the species, or with data from their description of the genus Myripristis when no specific data were provided in the description of the species. In accordance with Randall and Greenfield's (1996), body depth and head length were expressed as proportions of standard length, and orbit diameter and snout length as proportions of head length.

\section{RESULTS}

Myripristis violacea Bleeker, 1851

Description. Estimated TL $12 \mathrm{~cm}$; estimated SL $10 \mathrm{~cm}$; dorsal rays XI, 15; anal rays IV, 13; pectoral rays 15 ; body ovate, moderately deep, BD 2.4 in SL; caudal peduncle narrow, its depth 10.2 in SL; head large, HL 3.3 in SL; eye very large, OD 2.5 in HL; snout short and rounded, its length 5.1 in HL; mouth terminal, oblique, with corner of lips extending to vertical at rear edge of pupil; lower jaw faintly projecting when mouth closed; median dorsal part of head with two longitudinal ridges on either side of midline of head, extending from above lips to nape and ending before short median central ridge reaching scaled part of nape; two posteriorly radiating ridges on each side of first pair, extending from above anterior edge of pupil to above posterior edge of orbit; silver-coloured body with dorsal part of head bluish charcoal; ridges on head darker; edge of preopercle and opercular membrane dark brownish red; edges of scales above lateral line deep black, edges larger in anterior part; edges of scales below lateral line blackish grey, slightly reddening in last ventral row; upper part of spinous dorsal fin orange-red, lower part pinkish white; membrane between first two rays entirely orangered; last dorsal spine longer than penultimate and attached to first dorsal soft ray; dorsal and anal fins soft rays translucent whitish with lobe tips orange-red; first dorsal

\section{Table 1}

Selected morphometric and meristic characters of Myripristis violacea from Reunion Island, determined based on photographs

\begin{tabular}{lcc}
\hline Parameter & $\begin{array}{c}\text { Randall and } \\
\text { Greenfield 1996 }\end{array}$ & $\begin{array}{c}\text { Reunion Island } \\
\text { specimen } \\
\text { presently reported } \\
\text { study) }\end{array}$ \\
\hline$n$ & 85 & 1 \\
BD [in SL] & $2.0-3.4$ & ca. 2.4 \\
HL [in SL] & $2.65-3.15$ & 3.2 \\
Dorsal-fin rays & X-I, 13-16 & XI, 15 \\
Anal-fin rays & IV, 12-14 & IV, 13 \\
Pectoral-fin rays & $14-15$ & 15 \\
OD [in HL] & $1.8-2.7$ & 2.5 \\
Snout length [in HL] & $4.2-5.7$ & 5.1 \\
\hline
\end{tabular}

$\mathrm{SL}=$ standard length, $\mathrm{BD}=$ body depth, $\mathrm{HL}=$ head length, $\mathrm{OD}=$ orbit diameter. soft ray edged with white; anal spines white; caudal fin forked, colour translucent whitish with lobe tips orangered and procurrent rays white; base of pectoral fin black, rays slightly pinkish; pelvic fins pinkish with white spine. Remarks. This individual well agrees with the revisionary description of the species by Randall and Greenfield (1996); orbit diameter and snout length match with the description of the genus provided by these authors (see Table 1). The only difference between our individual and Randall and Greenfield's (1996: 51) description is the colour of the edges of scales under the lateral line ("brownish red, becoming more and more red ventrally"). Our individual only shows a last ventral row of slightly red-edged scales. We examined photographs of the species provided by reliable websites (Bray and Gomon 2019) and found that the scales edges below the lateral line may be either blackish grey or reddish brown, which suggests some variability in this character. It should be noted that during night-time monitoring all individuals of this group displayed pinkish scales with brownish red edges below the lateral line. In addition, Randall and Greenfield (1996) note that the broad nearblack edges of the scales situated anterodorsally on the body prevents any confusion with other species. Consequently, we can conclude that the fish we observed in Reunion Island belong to Myripristis violacea.

\section{DISCUSSION}

The two records of the species closest to Reunion Island, and therefore likely including the site of origin of the Reunion population of Myripristis violacea, are Madagascar (Fricke et al. 2018), and Raphael Island (National Museum of Natural History, Smithsonian Institution, USNM 387922), which is part of Saint Brandon Rocks. The minimum distances between Reunion and these islands are as follows: Madagascar about $680 \mathrm{~km}$, Saint Brandon Rocks about 660 km.-

Marine connectivity assessment must consider two main variables: the biological traits of larvae, and the physical processes of hydrodynamic transport (horizontally and vertically). Among the biological traits of larvae, the pelagic larval duration (PLD) is a key factor for broad-scale connectivity (Treml et al. 2012). Although a long PLD is not necessarily associated with broad-scale connectivity, due to the ability of larvae to influence their dispersal (Leis 2002), it is an important condition for longdistance dispersal.

The larval phase was studied in few Myripristis species, and the PLD range of Myripristis violacea is unknown. Tyler et al. (1993) found a range of 40-58 days from otolith analyses of seven individuals of Myripristis jacobus Cuvier, 1829. Craig et al. (2007) report B. Victor's unpublished data according to which the preliminary examination of M. berndti otoliths indicates a PLD of about 55 days. Dee and Radtke (1989) estimated a PLD of 115-125 days from the sagittae of a single individual of $M$. amaena. These authors stated that, although a series of otoliths would be required to fully interpret the duration of the larval stage of M. amaena, it is possible that this long-lived, slow-growing and slowmaturing species could have a long PLD. Moreover, Leis 
and Carson-Ewart (1997) reported the capture by crestnet of one juvenile of Myripristis sp. measuring $5.5 \mathrm{~cm}$ SL, which implies flexibility in pelagic juvenile duration, as pointed out by Craig et al. (2007). Although these results are not sufficient to assume a probable PLD of $M$. violacea based on an average of the documented PLD in related species, it seems reasonable to assume that this duration may be at least equivalent to the smallest documented value for the genus (40 days), which is sufficient to cover relatively long distances. In the Pacific Ocean, this species is known to have dispersed over vast distances between some remote island groups, reaching as distant groups the Cook Islands, Line Islands and Marquesas Islands; this fact also supports a relatively high PLD and an ability for longdistance dispersal.

Since genetic connectivity studies showed that larval dispersal may be consistent with regional current patterns in the Western Indian Ocean (Dorenbosch et al. 2006, Visram et al. 2010, Simpson et al. 2014), our assumptions about the origin of the Reunion Island's Myripristis violacea population will be mainly supported by patterns of the regional currents.

The oceanic circulation in the tropical south-western Indian Ocean is dominated by the westward flowing South Equatorial Current (SEC) in the upper $600 \mathrm{~m}$ between about $10^{\circ}$ and $15^{\circ} \mathrm{S}$ (Chapman et al. 2003). The SEC bifurcates into northern and southern cores when reaching the Mascarene Plateau (New et al. 2007). The northern core splits again when reaching the Comoros Islands, feeding into the north-flowing East African Coastal Current (Swallow et al. 1988), and into the southflowing Mozambique current (DiMarco et al. 2002). The southern core splits when reaching Madagascar, giving rise to the north-flowing North East Madagascar Current (NEMC) and the south-flowing South East Madagascar Current (SEMC) (Voldsund et al. 2017).

The current pattern along the east coast of Madagascar makes it unlikely that the Reunion Island population of Myripristis violacea originates from this island. NEMC and SEMC are strong coastal currents with maximum core velocity of $<150 \mathrm{~cm} \cdot \mathrm{s}^{-1}$ (Voldsund et al. 2017), that may act as an oceanographic barrier to larval dispersal. Only episodic events such as cyclones seem to allow in rare cases a connectivity between Madagascar and Reunion Island (Reid et al. 2016). In contrast, it seems possible that this population originates from Saint Brandon Rocks, possibly through a stepping-stone population living in Mauritius Island, located about $460 \mathrm{~km}$ south-southwest of Saint Brandon, although the species has not yet been recorded from this island. Indeed, a genetic study has led to the assumption that the Mascarene Plateau, which extends over $2300 \mathrm{~km}$ between the Seychelles Bank and Mauritius (Payet 2005), could act as a corridor for connectivity (Visram et al. 2010). The authors investigated the genetic structure of the blue-barred parrotfish, Scarus ghobban Forsskål in Niebuhr, 1775 in the Western Indian Ocean, and estimated the direction and number of migrants per generation to and from Kenya, Mauritius, Seychelles, and Tanzania. They found that the greatest contributor of migrants in Mauritius was Seychelles and vice-versa, and therefore assume a connection between the northern Seychelles and Mauritius Island through a steppingstone dispersal across the Mascarene Plateau. As Saint Brandon Rocks is situated on the Mascarene Plateau, and as M. violacea is recorded from the Seychelles (Smith and Smith 1963, Greenfield 1974), the same assumption can be made for this species. It is worth noting that the M. violacea population living at Saint Brandon could also originate from the Chagos Archipelago, where it has been recorded (Winterbottom et al. 1989, Winterbottom and Anderson 1997), through stepping stone populations. Sheppard et al. (2012) pointed out that currents passing across Chagos most often flow westward between May and December, and that larvae from Chagos moving at $0.5 \mathrm{~m} \cdot \mathrm{s}^{-1}$ would only need 25 days to cover the distance to the Saya de Malha reef system (1050 km apart) which is situated on the Mascarene Plateau. This duration is much shorter than the smallest documented PLD value in the genus Myripristis (40 days). Saint Brandon Rocks, situated about $600 \mathrm{~km}$ south of Saya de Malha, and about $460 \mathrm{~km}$ north-northeast of Mauritius, might have acted as a stepping-stone for the establishment of a Mauritian population of $M$. violacea originating from Chagos.

Considering the long distances that the larvae of this species seem to be able to cover, it can be assumed that the population of Myripristis violacea in Reunion Island originates directly from Saint Brandon Rocks. However, if the presence of the species in Mauritius was confirmed, the strongest likelihood would be that it originates from this place since the two islands, separated by about 170 $\mathrm{km}$, appear to be connected (Crochelet et al. 2013). A high resolution modelling strategy suggests that the currents around Mauritius and Reunion Island are generally oriented south-westward to the southeast of each island (Pous et al. 2014), which results in a likely dispersal of larvae from Mauritius to Reunion Island. Although the connectivity within the Mascarene islands is discussed (Muths et al. 2014), most studies seem to confirm that Mauritius and Reunion are connected (Wickel et al. 2016).

New sampling, particularly in Saya de Malha and Mauritius, could reinforce the hypothesis that the Mascarene Plateau acts as a connectivity corridor, and provide a better understanding of the distribution of Myripristis violacea.

Our observations extend the known depth range of this species. According to Allen et al. (2003), its depth range is $3-30 \mathrm{~m}$. Our observation were made at a depth of 1.2 $\mathrm{m}$. The updated depth range should therefore be 1-30 m.

Our study expands the distribution of Myripristis violacea to the southernmost part of the Mascarene Archipelago, and extends the known depth range of the species.

\section{ACKNOWLEDGEMENTS}

We thank Elisabeth Morcel (Sentinelles du Récif, RNMR) and Jean-Pascal Quod (ARVAM) for their assistance in the field and their photographs. We also thank two anonymous reviewers, whose comments improved the quality of the manuscript. 


\section{REFERENCES}

Allen G.R., Erdmann M.V. 2012. Reef fishes of the East Indies. Volume 1. Tropical Reef Research, Perth, Australia.

Allen G.R., Steene R., Humann P., Deloach N. 2003. Reef fish identification: Tropical Pacific. New World Publications, Jacksonville FL, USA.

Bray D.J., Gomon M.F. 2019. Myripristis violacea. In: Fishes of Australia. Museums of Victoria and OzFishNet, Australia. [Accessed on 22 January 2019.] http://fishesofaustralia.net.au/home/species/1822

Chapman P.S., Di Marco S.F., Davis R.E., Coward A.C. 2003. Flow at intermediate depths around Madagascar based on ALACE float trajectories. Deep-Sea Research II: Topical Studies in Oceanography 50 (12-13): 1957-1986. DOI: 10.1016/S0967-0645(03)00040-7

Craig M.T., Eble J.A., Bowen B.W., Robertson D.R. 2007. High genetic connectivity across the Indian and Pacific Oceans in the reef fish Myripristis berndti (Holocentridae). Marine Ecology Progress Series 334: 245-254. DOI: 10.3354/meps334245

Crochelet E., Chabanet P., Pothin K., Lagabrielle E., Roberts J., Pennober G., Lecomte-Finiger R., Petit M. 2013. Validation of a fish larvae dispersal model with otoliths data in the western Indian Ocean and implications for marine spatial planning in data-poor regions. Ocean and Coastal Management 86: 13-21. DOI: 10.1016/j.ocecoaman.2013.10.002

Dee A.J., Parrish J.D. 1994. Reproductive and trophic ecology of the soldierfish Myripristis amaena in tropical fisheries. Fishery Bulletin 92 (3): 516-530.

Dee A.J., Radtke R.L. 1989. Age and growth of the brick soldierfish, Myripristis amaena. Coral Reefs 8 (2): 79-85. DOI: 10.1007/BF00301806

DiMarco S.F., Chapman P., Nowlin W.D.jr., Hacker P., Donohue K., Luther M., Johnson G.C., Toole J. 2002. Volume transport and property distributions of the Mozambique Channel. Deep-Sea Research II: Topical Studies in Oceanography 49 (7-8): 14811511. DOI: 10.1016/S0967-0645(01)00159-X

Dorenbosch M., Pollux B.J.A., Pustjens A.Z., Rajagopal S., Nagelkerken I., van der Velde G., Moon-van der Staay S.Y. 2006. Population structure of the dory snapper, Lutjanus fulviflamma, in the western Indian Ocean revealed by means of AFLP fingerprinting. Hydrobiologia 568 (1): 43-53. DOI: 10.1007/s10750-006-0020-8

Dornburg A., Moore J.A., Webster R., Warren D.L., Brandley M.C., Iglesias T.L., Wainwright P.C., Near T.J. 2012. Molecular phylogenetics of squirrelfishes and soldierfishes (Teleostei: Beryciformes: Holocentridae): Reconciling more than 100 years of taxonomic confusion. Molecular Phylogenetics and Evolution 65 (2): 727-738. DOI: 10.1016/j.ympev.2012.07.020

Fricke R., Eschmeyer W.N., Fong J. (eds.) 2019a. Species by family/subfamily in Eschmeyer's catalog of Fishes. California Academy of Sciences, San Francisco, USA. [Accessed on 3 August 2019.] http://researcharchive. calacademy.org/research/ichthyology/catalog/Species ByFamily.asp
Fricke R., Eschmeyer W.N., van der Laan R. (eds.) 2019b. Eschmeyer's catalog of Fishes: Genera, species, references. California Academy of Sciences, San Francisco, USA. [Accessed on 6 February 2019.] http://researcharchive.calacademy.org/research/ ichthyology/catalog/fishcatmain.asp

Fricke R., Mahafina J., Behivoke F., Jaonalison H., Léopold M., Ponton D. 2018 Annotated checklist of the fishes of Madagascar, southwestern Indian Ocean, with 158 new records. FishTaxa 3 (1): 1-432.

Fricke R., Mulochau T., Durville P., Tessier E., Letourneur Y. 2009. Annotated checklist of the fish species (Pisces) of La Réunion, including a Red List of threatened and declining species. Stuttgarter Beiträge zur Naturkunde A, Neue Serie 2: 1-168.

Greenfield D.W. 1968. The zoogeography of Myripristis (Pisces: Holocentridae). Systematic Biology 17 (1): 76-87. DOI: 10.1093/sysbio/17.1.76

Greenfield D.W. 1974. A revision of the squirrelfish genus Myripristis Cuvier (Pisces: Holocentridae). Science Bulletin, Natural History Museum of Los Angeles County 19: 1-54.

Hobson E.S. 1972. Activity of Hawaiian reef fishes during the evening and morning transitions between daylight and darkness. Fishery Bulletin 70 (3): 715-740.

Kuiter R.H. 1992. Tropical reef fishes of the western Pacific: Indonesia and adjacent waters. Penerbit PT Gramedia Pustaka Utama, Jakarta, Indonesia.

Kuiter R.H., Tonozuka T. 2001. Pictorial guide to Indonesian reef fishes. Part 1. Eels- Snappers, Muraenidae - Lutjanidae. Zoonetics, Australia.

Leis J.M. 2002. Pacific coral-reef fishes: The implications of behaviour and ecology of larvae for biodiversity and conservation, and a reassessment of the open population paradigm. Environmental Biology of Fishes 65 (2): 199-208. DOI: 10.1023/A:1020096720543

Leis J.M., Carson-Ewart B.M. 1997. In situ swimming speeds of the late pelagic larvae of some Indo-Pacific coral-reef fishes. Marine Ecology Progress Series 159: 165-174. DOI: 10.3354/meps 159165

Lieske E., Myers R. 1994. Coral reef fishes. Indo-Pacific and Caribbean including the Red Sea. Collins Pocket Guide. Harper Collins Publishers, New York NY, USA.

Muths D., Tessier E., Bourjea J. 2014. Genetic structure of the reef grouper Epinephelus merra in the west Indian Ocean appears congruent with biogeographic and oceanographic boundaries. Marine Ecology 36 (3): 447-461. DOI: 10.1111/maec.12153

New A.L., Alderson S.G., Smeed D.A., Stansfield K.L. 2007. On the circulation of water masses across the Mascarene Plateau in the south Indian Ocean. DeepSea Research Part I: Oceanographic Research Papers 54 (1): 42-74. DOI: 10.1016/j.dsr.2006.08.016

Payet R. 2005. Research, assessment and management on the Mascarene Plateau: A large marine ecosystem perspective. Philosophical Transactions of the Royal Society A: Mathematical, Physical and Engineering Sciences 363 (1826): 295-307. DOI: 10.1098/ rsta.2004.1494 
Pous S., Lazure P., André G., Dumas F., Halo I., Penven P. 2014. Circulation around La Réunion and Mauritius islands in the south-western Indian Ocean: A modelling perspective. Journal of Geophysical Research: Oceans 119 (3): 1957-1976 DOI: 10.1002/2013JC009704

Randall J.E. 1984. Holocentridae. [30 unnumbered pp.] In: Fischer W., Bianchi G. (eds.) FAO species identification sheets for fishery purposes. Western Indian Ocean, Fishing area 51. Volume 2. Bony Fishes Families: Congiopodidae to Lophotidae. FAO, Rome.

Randall J.E., Greenfield D.W. 1996. Revision of the Indo-Pacific holocentrid fishes of the genus Myripristis, with descriptions of three new species. Indo-Pacific Fishes No. 25. Bernice Pauahi Bishop Museum, Honolulu HI, USA.

Reid K., Crochelet E., Bloomer P., Hoareau T.B. 2016. Investigating the origin of vagrant dusky groupers, Epinephelus marginatus (Lowe, 1834), in coastal waters of Réunion Island. Molecular Phylogenetics and Evolution 103: 98-103. DOI: 10.1016/j. ympev.2016.07.012

Sheppard C.R., Ateweberhan M., Bowen B.W., Carr P., Chen C.A., Clubbe C., Craig M.T., Ebinghaus R., Eble J., Fitzsimmons N., Gaither M.R., Gan C.-H., Gollock M., Guzman N., Graham N.A.J., Harris A., Jones R., Keshavmurthy S., Koldewey H., Lundin C.G., Mortimer J.A., Obura D., Pfeiffer M., Price A.R.G., Purkis S., Raines P., Readman J.W., Riegl B., Rogers A., Schleyer M., Seaward M.R.D., Sheppard A.L.S., Tamelander J., Turner J.R., Visram S., Vogler C., Vogt S., Wolschke H., Yang J.M.-C., Yang S.-Y., Yesson C. 2012. Reefs and islands of the Chagos Archipelago, Indian Ocean: Why it is the world's largest no-take marine protected area. Aquatic Conservation: Marine and Freshwater Ecosystems 22 (2): 232-261. DOI: 10.1002/aqc.1248

Simpson S.D., Harrison H.B., Claereboudt M.R., Planes S. 2014. Long-distance dispersal via ocean currents connects Omani clownfish populations throughout entire species range. PLoS ONE 9 (9): e107610. DOI: 10.1371/journal.pone.0107610

Smith J.L.B., Smith M.M. 1963. The fishes of Seychelles. Department of Ichthyology, Rhodes University, Grahamstown, South Africa.

Swallow J.C, Fieux M., Schott F. 1988. The boundary currents east and north of Madagascar 1. Geostrophic currents and transport. Journal of Geophysical Research: Oceans 93 (C5): 4951-4962. DOI: 10.1029/ JC093iC05p04951

Treml E.A., Roberts J.J., Chao Y., Halpin P.N., Possingham H.P., Riginos C. 2012. Reproductive output and duration of the pelagic larval stage determine seascape-wide connectivity of marine populations. Integrative and Comparative Biology 52 (4): 525-537. DOI: 10.1093/icb/ics101

Tyler J.C., Johnson G.D., Brothers E.B., Tyler D.M., Smith C.L. 1993. Comparative early life histories of western Atlantic squirrelfishes (Holocentridae): Age and settlement of rhynchichthys, meeki, and juvenile stages. Bulletin of Marine Science 53 (3): 1126-1150.

Visram S., Yang M.-C., Pillay R.M., Said S., Henriksson O., Grahn M., Chen C.A. 2010. Genetic connectivity and historical demography of the blue barred parrotfish (Scarus ghobban) in the western Indian Ocean. Marine Biology 157 (7): 1475-1487. DOI: 10.1007/s00227010-1422-8

Voldsund A., Aguiar-González B., Gammelsrød T., Krakstad J.-O., Ullgren J. 2017. Observations of the East Madagascar Current system: Dynamics and volume transports. Journal of Marine Research 75 (4): 531-555. DOI: 10.1357/002224017821836725

Wickel J., Pinault M., Fricke R. 2016. First record of a western Mascarene endemic, Halichoeres pelicieri (Actinopterygii: Perciformes: Labridae), from Reunion Island. Acta Ichthyologica et Piscatoria 46 (1): 33-35. DOI: 10.3750/AIP2016.46.1.04

Winterbottom R., Anderson C. 1997. A revised checklist of the epipelagic and shore fishes of the Chagos Archipelago, central Indian Ocean. Ichthyological Bulletin 66: 1-28.

Winterbottom R., Emery A.R., Holm E. 1989.An annotated checklist of the fishes of the Chagos Archipelago, central Indian Ocean. Royal Ontario Museum, Life Science Contributions No. 145. DOI: 10.5962/bhl.title.52237

Woods L.P., Sonoda P.M. 1973. Order Berycomorphi (Beryciformes). Pp. 263-396. In: Fishes of the western North Atlantic. Memoirs of the Sears Foundation of Marine Research, Memoir 1, Part 6.

Zehren S.J. 1979. The comparative osteology and phylogeny of the Beryciformes (Pisces: Teleostei). University of Chicago, Evolutionary Monographs No. 1.

Received: 3 April 2019

Accepted: 26 September 2019

Published electronically: 15 December 2019 